\title{
How to Increase the Participation of Customers to Location-Based Mobile Marketing: The Case of an Emerging Country
}

\author{
Turkey \\ Burak KIR ${ }^{1}$, Ipek ALTINBAŞAK FARINA ${ }^{2}$ \\ ${ }^{1}$ Ph.D. Management, Bahçeşehir University, Social Sciences Institute \\ burak.kir@gmail.com \\ ${ }^{2}$ Assoc. Prof., Bahçeşehir University, Faculty of Economics, Administrative and Social Sciences \\ ipek.altinbasak@bahcesehir.edu.tr
}

\begin{abstract}
Location-based service is a rapidly growing mobile service group in the mobile technology world. Upon their permissions, location information of consumers can be used to provide them with marketing-related messages and information. However, certain factors have to be considered in order to increase consumers' willingness to participate in location-based marketing activities. In this article, those factors have been investigated in an merging country, namely Turkey.

After a thorough literature review on mobile marketing, location-based mobile marketing and relevant areas topics discovered have been checked with mobile marketing professionals in Turkey through in-depth interviews. A model has been proposed covering factors that affect mobile marketing and a scale has been developed. Statistical analyses were performed using the data collected from 364 surveys. As a result, personal innovativeness, personalization, permission, perceived ease of use, mobile marketing experience, perceived usefulness and perceived trust have proven to have an effect on the intention of consumers to participate in location-based mobile marketing.
\end{abstract}

Key words: Location-Based Services, Location-Based Marketing, Mobile Marketing, Mobile Services, Mobile Technology, Adoption, Intention.

\section{INTRODUCTION}

Marketers always have difficulties in finding unique ways to communicate and engage with consumers. The penetration speed of the smart phones changed the marketing environment since the time spent on mobile devices has grown exponentially for the last decade. This new direct marketing environment turned into a fundamental segment named "mobile marketing" and mobile marketing has become a crucial component of an advanced marketing technique.

In recent years, with the significant increasein thepopularity of mobile marketing, marketers have initiated using consumers' location information in their mobile marketing activities. Consumers reach various products or services by controlling the real world remotely via their locations while they are mobile.

While businesses can generate revenues by integrating location information with their mobile marketing strategies, customers can benefit from these strategies with regard to confusion reduction, consumption experience and delivery of high-quality service options [73].

With recent developmentsof location-based servicesand technology, it is easier now to pinpoint the location of smart devices. The information gathered from these devices gives insights to businesses as to what the device user is doing at a certain location.For instance, traffic flow patterns can be learned by GPS (Global Positioning System) signals and businesses use this information to choose where and when they will present their outdoor advertising.

In this article, by evaluating the past studies in the field, a comprehensive model of the factors affecting the adoption of location-based marketing is proposed. The understanding of these factors is expectedto be an important contribution to mobile marketing literature and the industry enabling the marketers in Turkey to take the required precautions once theydecide to make location-based technologies part of their marketing strategy.

\section{THEORETICAL BACKGROUND}

Before starting the field study, a comprehensive literature review on mobile marketing and location-based marketing related issues have been carried out. For many years, marketers have been applying the techniques of mass marketing characterized as providing customary offers to a mass of clients [84]. Today's marketing managers have been compelled to grow new marketing approaches to contact consumers in new and unpredicted ways [48].Although internet has for long been a stage for marketing, with the quick advancement inside the mobile innovation industry, new alternatives have emerged. Therefore, it is worth examininginitially the mobile marketing and location-based marketing concepts.

\subsection{Mobile Marketing and Location-based Mobile Marketing (LBM)}

$\mathbf{3 0 0 1}$ | P a g e

Nove m b e r 2016 
The definition and content of mobile marketing havechanged in years as defined by different scholars in literature. Haghirian[28] defines mobile marketing as an instance of marketing in the setting of a mobile environment. In 2009, Shankar and Balasubramanian [80] focused on the communication and made a definition of mobile marketing as "two or multiple ways of correspondence happening between an organization and its consumers by utilizing mobile innovation on the riseof exploring native marketing exercises and their significance". The definition of Mobile Marketing Association is about the practices that empower associations to connect their consumers by an intelligent and proper path through any mobile phone (Mobile Marketing Association, 2010).

Location-based marketing(LBM) is a sub-thought of mobile marketing and is characterized as an application that utilizes geographic location to convey or upgrade a marketing message (Mobile Marketing Association, 2011). Especially in the recent decade, the development of smart mobile phones has carried customary advertising one step further, opening up the significance of location, time, and personalization [79].Therefore, there is significant number of research in the marketing field to highlight the advantages of LBM. One of the great potentials for location-based mobile services in marketing is the ubiquity of mobile consumers and their devices[42].Also, location-based marketing is defined as a remarkable method for focusing on and conveying exceptionally significant messages to consumers (Mobile Marketing Association, 2011).

Since the consumers of today rather expect customized messages and personalized value by marketing activities [79], they may be persuaded to unveil individual datato get customized messages in return[92].Utilizing location-based marketing and accepting customized campaign messages for products and services that consumers demand at any location might be a great advantage therefor. Furthermore, consumers would then spend time onsearching for messages appropriate for them, but would receive specific offerscustom-made to their necessities [2].It might be noted that locationbased marketing is an entirely new tool for marketers, hence it issignificant to examine more on how the consumers feel about this service [86].

In the area of mobile marketing and location-based mobile marketing, there are studies regardingconsumer behaviorandadoption to mobile marketing [13]. Studies typically attempt to investigate mobile marketing from the perspective of consumer behavior while putting an emphasis on issues like perceived ease of use, trust, privacy [45, 93], attitudes [51], and intention[95].In their study, Lee and Murphy [52] mostly mentioned the social and peer effect of mobile marketing and specified that peer's opinion is also one of the main factors affecting the adoption to mobile marketing activities.Similarly, some of the scholars investigated the content received via mobile [88] setting of the promoting message received via mobile [6], culture [31], mobile device's usefulness and ease of use [69], perceived risk and complexity [47].

In the following sections, the literature regarding the concepts related to LBM such as perceived usefulness, personalization, permission, perceived behavior control, personal innovativeness, etc. are presented.

\subsection{Perceived Usefulness}

Perceived usefulness is the degree to which a man trusts that using a particular system would enhance his/ her work execution [19]. Furthermore, perceived usefulness is defined as one of the main dimensions of the technology acceptance model -TAM [87].

Merisavo, et al. [62]claim that perceived usefulness, importance, money-related impetuses, and additionally excitement and information value are critical variables influencing customer acknowledgement of mobile advertising.

Perceived usefulness has been observed to be a general precursor for customers' courses of action to utilize various sorts of mobile services; delight, for instance, radiated an impression of being particularly crucial as a helper for utilizing innovative services [54]. Moreover, Nysveen et al. [64] demonstrate that the intention to use mobile devices can be driven by perceived enjoyment, perceived usefulness, and perceived expressiveness.

\subsection{Personalization}

The supporters of direct marketing perspective energetically believe in the power of favorable aspects of personalization [35].

Personalization reflects the degree to which information or organization is pulledto address the issues of the individual visitor [20]. In connection with business environment,Schultz and Bailey [82] claimed that personalization clearly describes the new smart business focus as opposed to the standard, outbound mass business segment.Nowak et al., [63] state that personalized messages assemble individuals' motivation to take care of marketing-related data and activate ideal states of mind towards the campaign and promoter.

Furthermore, online environment has also allowed marketers to gather profiles of their customers and develop a natural relationship so that developing trades could be rebuilt to address the desires and needs of a segment or even an individual [91].In their most recent study, $\mathrm{He}$ et al.[32]conducted an observational investigation and demonstrated that consumer innovation, personalization, permission and intention had immediate or direct effect on the plan of customers to take part in mobile marketing.

\subsection{Permission}

3002 | P a g e

$\mathrm{Novem}$ ber 2016 council for Innovative Research w w w. cir world.com 
Permission with regard to content importance and control over the location-based mobile marketing campaignsare among the basic variables for the engagement of mobile marketing messages. According to literature,permission has an influence on consumer intent to use mobile advertising offers and the message sent to opt-in users is typically more accepted by customers [5].

The model of Jayawardhena, Chanaka et al.[40] hypothesizes that four variables namely, personal trust, institutional trust, mobile marketing experience, and perceived control have direct effects on permission. Besides permission-based mobile marketing is viewed as more satisfactory when conveyed by a trusted source rather than an obscure one [55].

\subsection{Perceived Behavior Control}

In their study, Jayawardhena et al. [40] found that for more experienced consumers on mobile marketing, there is less effect of perceived control on intention. Also the research model ofLee et al. [51] ]asserts that user control has a direct impact on trust and trust has a direct effect on attitude towards using mobile commerce and behavioral intention to use mobile commerce. Further investigations of Persaud and Azhar[70] suggest that while permission and trust in a brand are the reasons for a client to enthusiastically respond to mobile marketing, consumers are stressed with regard to avoiding riskand need to have some control over the mobile marketing service or campaigns.

\subsection{Personal Innovativeness}

In diffusion of innovations theory, Rogers [75] used sociology, psychology, and communications to create a methodology to study the dissemination of innovations.

Im et al. [39] demonstrated that the relationship between the customer innovation and conducting the adoption of a new technology application is distinctly related. Also, Hirunyawipada and Paswan[33] found that space spesificinnovativeness improves the real adoption of the cutting edge technology. Li[58] utilized the central variables of the unified theory of acceptance and use of technology

With UTAUT model, the personal innovativeness of Roger's innovation diffusion theory explores consumers' attitude and acceptance of mobile advertisementAs per the research conducted by Huang, Hsieh and Chang [38],consumers with higher innovative characteristics for location-based services have stronger tendency to look for significant information.In their study, Rohm et al. [76]set forth that innovative consumershave positive thoughtstowards mobilemarketing.

\subsection{Mobile Marketing Experience}

Consumers' interactions with their mobile phones do not only consist of a marketing experience; individuals may be unwilling to access the marketing activities via their mobile phones[22].Since mobile marketing is a generally new movement for a greater part of consumers, it might be considered to be more risky, therefore mobile consumers might feel confident if they have positive personal experience before[40].Jayawardhena et al. [40]also declared that mobile marketing is a comparatively innovative marketing method that might interest only a part of consumers and might not be seen trustworthy, thus consumers may depend on their experience that can be acquired only by joining to mobile marketing campaigns. In their study,Lin et al.[60] stated that successful experiences of early adopters are useful in persuading the majority of early advertisers to experience location-based mobile marketing.

\subsection{Perceived Ease of Use}

In their study, Davis et al. [19]argue that perceived ease of use is a significant secondary determinant of people's intentions to use computers by comparing technology acceptance model and theory of reasoned action to investigate user acceptance of computer technology. Furtherstudies in the electronic and mobile commerce area exhibit the positive relationship between perceived ease of use and intention to use mobile marketing [37]. Later, based on their study, Nysveen et al. [64] confirm that perceived ease of use is an important antecedent of consumers' intentions to use mobile services. In 2009, Roca et al. [74] provedthat there is a direct relationship between perceived ease of use and intention to use LBM.

\subsection{Perceived Trust}

Siau and Shen[83] express that gaining consumers' trust in mobile business is a challenge.Analysis and results section of Kleijnen, Ko and Martin's [47]study titled "Finding the Rules While Playing the Game" demonstrates that perceived risk and trust are the most essential variables in adopting mobile services. In their study,Basheer et al. [10] express that it is ordinary that in mobile marketing, where the apparent risk and instability are high, trust will affect consumers' intent to join permission-based mobile campaigns.In mobile services space, Yeh [96] as well as Li [57]arrived at a conclusion that mobile web attributes and the mobile web site plan all togetherare essential determinants of mobile trust.

\subsection{Privacy}

Consequences of the investigation of Consolvo et al. [17] about location-based marketing demonstrated that the most crucial variables were; (a) who was asking the information, (b) why the requester needed the member's private info, and (c) what level of point of interest would be the most valuable to the requester.Basheer and Alnawas[10]likewise state in their article that consumers see their mobile phones as their very own significant part thus mobile marketing push messages might be seen as an interruption of clients' privacy.Reliable with the psychology literature, perceived privacy

$\mathbf{3 0 0 3}$ | P a g e
Nove m b e r 2016 council for Innovative Research w w w. cir world.com 
risk adversely impacts the individual's perceived usefulness of location-based services [93]. In their research about user privacy in location-aware services,Beresford and Stajano[12] asserted that the client can settle on choices about whether to disable some location-based services or to alter their movements in order to gain increased privacy.

\subsection{Intention}

In the context of information systems and technology consumers' intention to use mobile services, adoptionand usability have been examined on the ground of extended version of TAM'scapacity to explain 40 percent of consumers' intention to use different types of technology whereas extended model explains 72.3 percent of it [87]. Moreover,Merisavo et al. [62] demonstrate that the utility and significance of mobile marketing messages influence clients' appropriation to mobile marketing. Also Bauer et al. [11] argued that if mobile marketing messages were only creatively designed and attracted the attention of consumers with their informative quality then consumers might have a positive intention.

\section{METHODOLOGY}

In this study, procedures with both exploratory (qualitative) and descriptive (quantitative) techniques have been used. The objective of the exploratory research is to discover insights to better understand the dependent and independent variables to be used for the model. On the other hand, the quantitative study addresses the issue of adoption to location-based mobile marketing by defining a specific set of variables and procedures for measuring them.

Literature regarding location-based mobile marketing, perceived usefulness, perceived ease of use, perceived trust, perceived behavioral control, personalization,mobile marketing experience, and permission have been analyzed to determine factors affecting adoption of location-based mobile marketing. After having determined the variables mentioned in literature, in-depth interviews have been carried out with the professionals of the mobile sector in Turkey. Since the professionals were well aware of the realities of location-based mobile services and marketing environment in Turkey, organizing the questions and clarifying the reason and the nature of the study were somewhat easier. Upon the insight obtained, the model has been defined and the relevant scales have been adapted. Scales that were in English Language have been translated to Turkish and a test group has been used to operationalize the survey questions and eliminate some misunderstandings due to the language. The surveys have been pre-tested and the research instruments have been refined[18]. After corrections, a pilot study has been conducted with 47 valid surveyscollected online and the model was approved. Between April-May 2016, the main field study has been carried out through Survey monkey using nonprobability sampling. A total of 400 questionnaires have been collected out of which 364 were found to be suitable for further analysis.

SPSS and AMOS software were used to develop a structural model and to test the parameters of the model to understand whether the factors determined in the model are affecting the adoption directly or indirectly.

\section{DATA ANALYSIS}

\subsection{Qualitative Research Procedures and Insights}

Table 4.1: Characteristics of the Participants in in-Depth Interviews

\begin{tabular}{|c|c|c|c|c|}
\hline Participant & $\begin{array}{l}\text { Date of } \\
\text { Birth }\end{array}$ & Education & Company/Title & $\begin{array}{l}\text { Years in the } \\
\text { Sector }\end{array}$ \\
\hline Participant 1 & 1974 & Computer Engineering & Technology Company/CTO & 15 \\
\hline Participant 2 & 1974 & $\begin{array}{l}\text { Economics with MBA, } \\
\text { Marketing PhD Candidate }\end{array}$ & Mobile Operator/Director & 11 \\
\hline Participant 3 & 1984 & $\begin{array}{l}\text { Economics with MA, MIS, } \\
\text { Management PhD } \\
\text { Candidate }\end{array}$ & $\begin{array}{l}\text { Technology } \\
\text { Company/Owner }\end{array}$ & 4 \\
\hline Participant 4 & 1964 & Political Science & $\begin{array}{l}\text { Consultancy } \\
\text { Company/Owner }\end{array}$ & 18 \\
\hline Participant 5 & 1976 & Industrial Design & $\begin{array}{l}\text { Mobile Technology } \\
\text { Company/ } \\
\text { Managing Director }\end{array}$ & 10 \\
\hline Participant 6 & 1976 & Economist & Mobile Operator/Director & 15 \\
\hline Participant 7 & 1970 & $\begin{array}{l}\text { Computer Science, MBA, } \\
\text { PhdManament }\end{array}$ & $\begin{array}{l}\text { Mobile Software } \\
\text { Development } \\
\text { Company/Partner }\end{array}$ & 16 \\
\hline
\end{tabular}

Questions for the in-depth interviews were partitioned into themes identified as perceived usefulness, perceived ease of use, perceived privacy, personalization, perceived behavior control, perceived trust, permission, and personal innovativeness taken from literature.Therefore, a structured questionnaire has been used. 
The research is aimed to understand the opinion of professionals about the behavioral constructs of mobile customers affecting their intention to utilize location-based marketing activities and campaigns.

The professionals point out that particularly traditionalist customers behave more precautiousin situations they do not feel certain about. Hence, consumers' perceived trust and behavioral control might influence marketing campaigns. Professionals believethat usually opt-in users show more interest in accepting LBM offers. Furthermore, permission-based mobile marketing is expected to empower marketers with higher reaction rates and prevalent rates of profitability. Sector professionals agree on that personalization is essential to perform a qualified customer relationship management. They specified that perceived ease of use is one of the important components that add to the fast development of location-based mobile marketing success.Participants all agree that privacy is very important and this issue has to be managed carefullyin relation to location-based mobile services.

Since the smart phone technologies are focusing strongly on the ease of use, in general participants declared that personal innovativeness might be anindirect factor affecting adoption to location-based services for the Turkish market.

\subsection{Quantitative Research Procedures and Insights}

Although the research on mobile marketing and LBM has evolved and enlarged in the recent years, it can still be observed that in each research, different components related to phenomena had been used. In this study, a comprehensive model including a vast variety of variables is tested. The relationship between variables and their impact on participating inlocation-basedmobile marketing are examined after the statistical analysis presented below.

\subsubsection{Research Model and Hypotheses}

Constructs of factors affecting adoption of location-based mobile marketing are determined in line with studies in literature and adaptations have been made as a result of in-depth interviews.

The proposed model (please see Figure 4.1) and the related hypotheses are presented below.

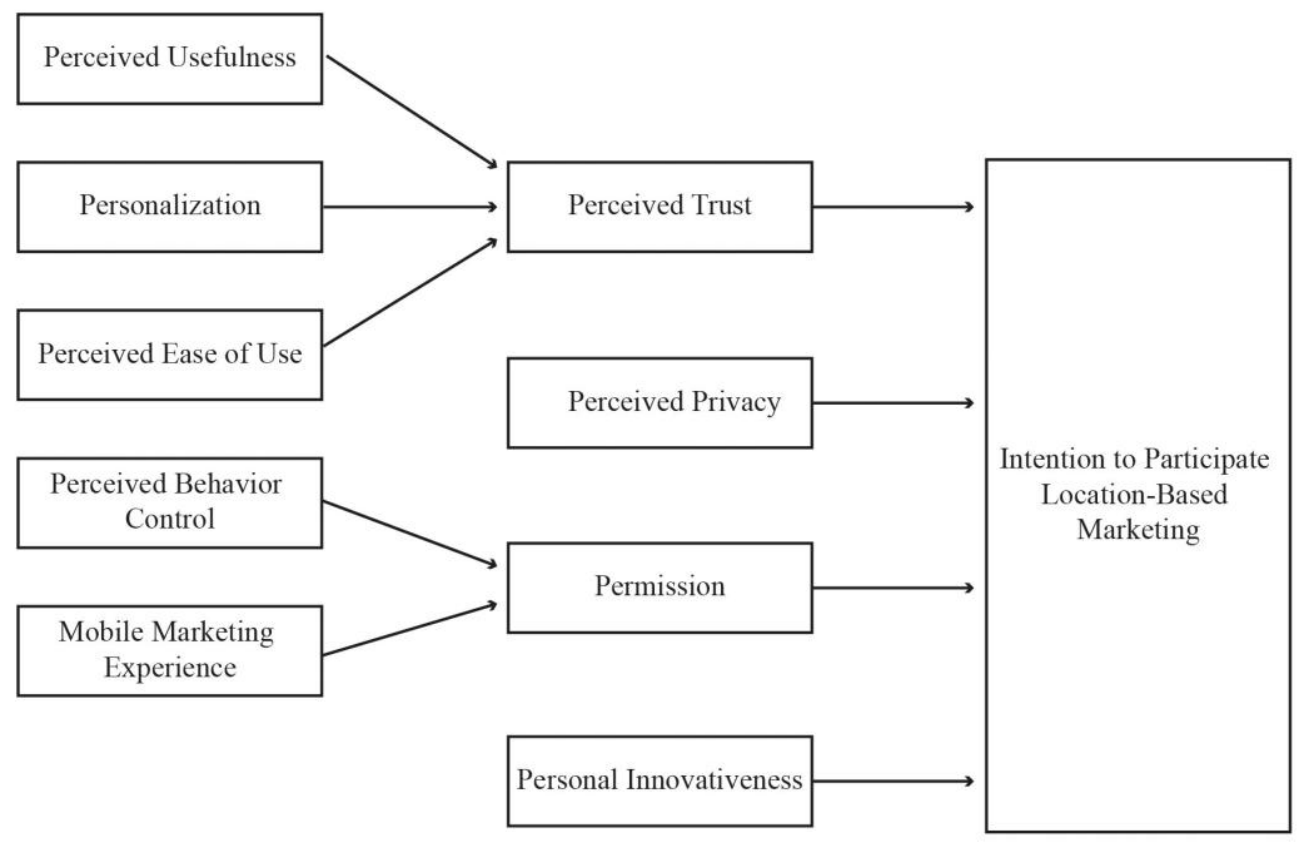

Figure 4.1: Research model

In accordance with the proposed model hypotheses:

H1: Perceived usefulness has a positive effect on perceived trust.

H2: Personalization has a positive effect on perceived trust.

H3: Perceived ease of use has a positive effecton perceived trust.

H4: Perceived trust has a positive effect on intention to participate in location-based mobile marketing.

H5: Perceived privacy has a positive effect on intention to participate in location-based mobile marketing. 
International Journal of Management and Information Technology

H6: Perceived behavior control has a positive effect on permission.

H7: Mobile marketing experience has a positive effect on permission.

H8: Permission has a positive effect on intention to participate in location-based mobile marketing.

H9: Personal Innovativeness has a positive effect on intention to participate in location-based mobile marketing.

\subsubsection{Sampling Method}

Convenience sampling constitutes non-random (non-probability) sampling method that has been used during the research.

Convenience samples are a type of non-probability sampling normally comprising persons who are either known by the examiners and/or are promptly accessible to the specialists.

Sample members were not selected at random from the population of all adults but users of mobile phones (phones allowing their owners to get SMSs, MMSs and mobile marketing push messages) between ages 18 to $46+$ have been targeted.

Link of questionnaires (https://tr.surveymonkey.com/r/LBM_BurakKir) were sent to approximately 420 potential responders and 364 valid questionnaires have been collected. Despite the fact that sample size is vital in a factor analysis, there are differing suppositions and a few controlling dependable guidelines are referred to in the writing.

Hair et al. [29] proposed that example sizes should be 100 or more prominent. Various authors refer to the work of Comrey and Lee [16]in their manual for test sizes: 100 as poor, 200 as reasonable, 300 as good, 500 as great, and 1000 or more as phenomenal. Malhotra[61] hascomputed using a sample size formula as

$$
z^{2 *}(\pi) *(1-\pi) / c^{2}
$$

wherez is the value for the determined confidence level (1.96); $p$ is the level of precision; $c$ is the confidence interval (0.05) and suggests that $\pi$ value is used as 0.5. Taking this formula and the study of Hair et al. [29] and Krejcie and Morgan [49]into consideration which simplified the sample size decisions in research when the population ( $N$ ) is higher than one million with a standard error of $0.05,364$ valid survey results out of more than 420 online collected surveys have been used for this study.

Others, for example, Guadagnoli and Velicer[24] found that arrangements with relationship coefficients $>0.80$ require smaller sample sizes, while Sapnas and Zeller[78] pointed out that even 50 cases might be satisfactory for component examination.

\subsubsection{Scales Used in the Study}

Table 4.2: Scales Used

\begin{tabular}{|l|ll|l|}
\hline Scale Name & Scale Questions & Source \\
\hline $\begin{array}{l}\text { Perceived } \\
\text { Usefulness }\end{array}$ & $\begin{array}{l}\text { Receiving messages gives me topical } \\
\text { information }\end{array}$ & $\begin{array}{l}\text { Receiving messages saves me time } \\
\text { Adapted from Davis (1989), } \\
\text { Davis, Bagozzi and Warshaw } \\
\text { (1989), and Venkatesh and } \\
\text { Davis (2000). }\end{array}$ \\
\hline $\begin{array}{l}\text { Personalizatio } \\
\text { benefits }\end{array}$ & $\begin{array}{l}\text { Mobile location-based marketing campaigns } \\
\text { are tailor-made for me, }\end{array}$ & $\begin{array}{l}\text { Mobile location-based marketing campaigns } \\
\text { are tailored to my situation }\end{array}$ & $\begin{array}{l}\text { Adapted from Srinivasan, } \\
\text { S.S., R. Anderson, and, K. }\end{array}$ \\
\hline Intention & $\begin{array}{l}\text { Mobile location-based marketing campaigns } \\
\text { makes me feel that I am a unique customer }\end{array}$ & $\begin{array}{l}\text { I am willing to click location-based mobile } \\
\text { marketing campaign invitations }\end{array}$ \\
\hline $\begin{array}{l}\text { I expect to click location-based mobile } \\
\text { marketing campaign invitations in the future } \\
\text { I expect that location-based mobile marketing } \\
\text { systems would make everything easier in the } \\
\text { future }\end{array}$ & $\begin{array}{l}\text { Adapted from B. Suh, I. Han } \\
\text { (2006). }\end{array}$ & \\
\hline
\end{tabular}




\begin{tabular}{|c|c|c|}
\hline Permission & $\begin{array}{l}\text { - I am willing to give my mobile phone number } \\
\text { to a company that practises mobile marketing. } \\
\text { - I am willing to provide my background } \\
\text { information (e.g. gender, age) to a company } \\
\text { practising mobile marketing. } \\
\text { I am willing to participate in mobile marketing } \\
\text { activities. }\end{array}$ & $\begin{array}{l}\text { Adapted from Bauer et al. } \\
\text { (2005) and Tsang et al. } \\
(2004) \text {. }\end{array}$ \\
\hline $\begin{array}{l}\text { Perceived } \\
\text { Behavirol } \\
\text { Control }\end{array}$ & $\begin{array}{l}\text { - I find it important that I can choose the form of } \\
\text { the mobile location-based marketing } \\
\text { campaigns (e.g. informing only, inviting to } \\
\text { participation etc.). } \\
\text { - I find it important that I can easily control the } \\
\text { number of mobile location-based marketing } \\
\text { campaign messages I receive. } \\
\text { I find it important that I can easily stop mobile } \\
\text { location-based marketing campaign } \\
\text { messages. }\end{array}$ & $\begin{array}{l}\text { Adapted from Mathieson } \\
\text { (1991), Taylor and Todd } \\
\text { (1995b), and Merisavo et al. } \\
\text { (2007). }\end{array}$ \\
\hline $\begin{array}{l}\text { Personal } \\
\text { Innovativenes } \\
\text { s }\end{array}$ & $\begin{array}{l}\text { - If I heard about a new information technology, } \\
\text { I would look for ways to experiment with it. } \\
\text { Among my peers, I am usually the first to try } \\
\text { out new information technologies. } \\
\text { - I like to experiment with new information } \\
\text { technologies. }\end{array}$ & $\begin{array}{l}\text { Adapted from Agarwal, R., } \\
\text { and Prasad, J. (1998). }\end{array}$ \\
\hline $\begin{array}{l}\text { Mobile } \\
\text { Marketing } \\
\text { Experience }\end{array}$ & $\begin{array}{l}\text { - When I was participating in location-based } \\
\text { mobile marketing activities, I felt totally } \\
\text { captivated. } \\
\text { - When I was navigating location-based mobile } \\
\text { marketing activities, time seemed to pass very } \\
\text { quickly. } \\
\text { When I visited location-based mobile } \\
\text { marketing promotion page, nothing seemed to } \\
\text { matter to me. }\end{array}$ & $\begin{array}{l}\text { Adapted from Novak, T.P., } \\
\text { Hoffman, D.L., Duhachek, A., } \\
2003 .\end{array}$ \\
\hline $\begin{array}{l}\text { Perceived } \\
\text { Ease of Use }\end{array}$ & $\begin{array}{l}\text { - Learning to participate mobile location-based } \\
\text { marketing and promotional campaigns is easy } \\
\text { for me } \\
\text { - It would be easy for me to become skillful at } \\
\text { participating mobile location-based marketing } \\
\text { and promotional campaigns } \\
\text { - My interactions with the mobile location-based } \\
\text { promotional campaigns are clear and } \\
\text { understandable }\end{array}$ & $\begin{array}{l}\text { Adapted from Davis, F.D., } \\
\text { Bagozzi, R.P. and Warshaw, } \\
\text { P.R. (1989), }\end{array}$ \\
\hline $\begin{array}{l}\text { Perceived } \\
\text { Trust }\end{array}$ & $\begin{array}{l}\text { Mobile location-based marketing } \\
\text { campaign messages are trustworthy } \\
\text { Mobile location-based marketing } \\
\text { campaign messages have a good reputation } \\
\text { Mobile location-based marketing } \\
\text { campaign systems are competent and } \\
\text { effective. }\end{array}$ & $\begin{array}{l}\text { Adapted from Jarvenpaa, S.L. } \\
\text { et al (2000), McKnight, D.H.et } \\
\text { al (2002), Koufaris, M et al. } \\
(2004) \text {. }\end{array}$ \\
\hline
\end{tabular}


International Journal of Management and Information Technology

\begin{tabular}{|l|l|l|}
\hline & $\begin{array}{l}\text { Mobile location-based marketing providers } \\
\text { may keep my private information (including my } \\
\text { location) in a non-secure manner. }\end{array}$ & \\
$\begin{array}{l}\text { Perceived } \\
\text { Privacy }\end{array}$ & $\begin{array}{l}\text { Mobile location-based marketing providers } \\
\text { may not take measures to prevent } \\
\text { unauthorized access to my personal } \\
\text { information. }\end{array}$ & $\begin{array}{l}\text { Adapted from Smith, H. J., } \\
\text { Milberg, J. S., \& Burke, J. S. } \\
(1996) .\end{array}$ \\
\hline $\begin{array}{l}\text { Mobile location-based marketing providers } \\
\text { may divulge my personal information to } \\
\text { unauthorized parties without my consent }\end{array}$ & \\
\hline
\end{tabular}

\subsubsection{Statistical Analysis and Results}

In this section, the demographic characteristics of the participantshave been determined, the statistical tests have been performed and the findings have been presented.

\subsubsection{Demographic Information}

Table 4.3: Age, Gender and Education of Participants

\begin{tabular}{|c|c|c|c|}
\hline & Frequency & Percentage & $\begin{array}{l}\text { Cumulative } \\
\text { Percentage }\end{array}$ \\
\hline \multicolumn{4}{|l|}{ Age } \\
\hline $18-30$ & 118 & $32.42 \%$ & $32.42 \%$ \\
\hline $31-35$ & 56 & $15.38 \%$ & $47.80 \%$ \\
\hline $36-40$ & 75 & $20.60 \%$ & $68.41 \%$ \\
\hline $41-45$ & 53 & $14.56 \%$ & $82.97 \%$ \\
\hline $46+$ & 62 & $17.03 \%$ & $100.00 \%$ \\
\hline \multicolumn{4}{|l|}{ Gender } \\
\hline Male & 183 & $50.27 \%$ & $50.27 \%$ \\
\hline Female & 181 & $49.73 \%$ & $100.00 \%$ \\
\hline \multicolumn{4}{|l|}{ Education } \\
\hline High School & 15 & $4.12 \%$ & $4.12 \%$ \\
\hline University & 186 & $51.10 \%$ & $55.22 \%$ \\
\hline Masters & & & \\
\hline Degree & 135 & $37.09 \%$ & $92.31 \%$ \\
\hline Phd & 28 & $7.69 \%$ & $100.00 \%$ \\
\hline $\begin{array}{l}\text { Total } \\
\text { Participants }\end{array}$ & 364 & $100.00 \%$ & \\
\hline
\end{tabular}

\subsubsection{Internal Consistency and Exploratory Factor Analysis (EFA)}

Factor investigation tries to unite inter-correlated variables under broader, basic variables. More particularly, the goal of component examination is "to reduce the dimensionality of the special space and to give an interpretation to the new space, navigated by a decreased number of new estimates which should underlie the old ones" [3] or to clear up the distinction in the variables with respect to concealed unmoving parts" [26].

Discriminant validity confirmation has been made by analyzing the factor correlation matrix. In this matrix, variables with inter-correlations are represented. 
International Journal of Management and Information Technology Campbell and Fiske [15] presented the idea of discriminant validity on assessing test validity. They focused on the significance of utilizing both discriminant and convergent approval systems while evaluating new tests. Although there is no standard value for discriminant validity, a result less than 0.85 tell us that discriminant validity likely exists between the two scales. A result greater than 0.85 , however, tells us that the two constructs overlap greatly and they are possibly measuring the same thing. Therefore, we cannot claim discriminant validity between them. There were no cross loadings between the variables and the results of discriminant validity tests provided in Table 4.4.

Cronbach's Alpha coefficient of 0.70 or higher is viewed as "satisfactory" in internal consistency and close to1.0 is the sign of solid reliability [71].

Kaiser-Meyer-Olkin (KMO) records with 0.50 were considered to be suitable for factor analysis. Bartlett's Test of Sphericity should be significant $(p<0.05)$ for the analysis to be appropriate $[29,85]$.

In this research,as shown in Table 4.5 and 4.6,exploratory factor analysis results were satisfactory in both Cronbach's alpha coefficient and Kaiser-Meyer-Olkin (KMO) measurements. Indicators have been loaded on expected factors and the communalities are greater than 0.50 . The average factor loadings of all factors are above 0.70 which confirm the convergent validity.

Table 4.4: Discriminant Validity Through Factor Correlations Matrix

\begin{tabular}{|c|c|c|c|c|c|c|c|c|c|c|}
\hline $\begin{array}{l}\text { Factor } \\
\text { Correlations }\end{array}$ & PU & PERS & PERM & PBC & INO & EXP & PEU & TRUST & PRI & INT \\
\hline $\begin{array}{l}\text { Perceived } \\
\text { Usefulness } \\
\text { (PU) }\end{array}$ & 1 & & & & & & & & & \\
\hline $\begin{array}{l}\text { Personalization } \\
\text { (PERS) }\end{array}$ & 0.589 & 1 & & & & & & & & \\
\hline $\begin{array}{l}\text { Permission } \\
\text { (PERM) }\end{array}$ & 0.607 & 0.595 & 1 & & & & & & & \\
\hline $\begin{array}{l}\text { Perceived } \\
\text { Behavior } \\
\text { Control (PBC) }\end{array}$ & 0.280 & 0.089 & 0.200 & 1 & & & & & & \\
\hline $\begin{array}{l}\text { Personal } \\
\text { Innovativeness } \\
\text { (INOV) }\end{array}$ & 0.227 & 0.180 & 0.274 & 0.343 & 1 & & & & & \\
\hline $\begin{array}{l}\text { Mobile } \\
\text { Marketing Exp. } \\
\text { (EXP) }\end{array}$ & 0.657 & 0.579 & 0.687 & 0.239 & 0.348 & 1 & & & & \\
\hline $\begin{array}{l}\text { Perceived } \\
\text { Ease of Use } \\
\text { (PEU) }\end{array}$ & 0.550 & 0.481 & 0.503 & 0.320 & 0.370 & 0.579 & 1 & & & \\
\hline $\begin{array}{l}\text { Perceived } \\
\text { Trust (TRUST) }\end{array}$ & 0.593 & 0.507 & 0.600 & 0.254 & 0.248 & 0.684 & 0.647 & 1 & & \\
\hline $\begin{array}{l}\text { Perceived } \\
\text { Privacy (PRI) }\end{array}$ & 0.029 & $\begin{array}{c}- \\
0.153\end{array}$ & -0.059 & 0.292 & 0.128 & $0 . \overline{0} 4$ & 0.047 & -0.028 & 1 & \\
\hline Intention (INT) & 0.579 & 0.507 & 0.645 & 0.254 & 0.323 & 0.709 & 0.592 & 0.686 & 0.037 & 1 \\
\hline
\end{tabular}


Table 4.5: Factor Loading Results of Scales

\begin{tabular}{|c|c|}
\hline Factors and Related Items & $\begin{array}{l}\text { Factor Loading } \\
\text { Scores }\end{array}$ \\
\hline \multicolumn{2}{|l|}{ Perceived Usefullness } \\
\hline Receiving messages gives me topical information & 0.847 \\
\hline Receiving messages saves me time & 0.816 \\
\hline Receiving messages gives me monetary benefits & 0.798 \\
\hline \multicolumn{2}{|l|}{ Personalization } \\
\hline Mobile location based marketing campaigns are tailor-made for me. & 0.833 \\
\hline Mobile location based marketing campaigns are tailored to my situation. & 0.827 \\
\hline Mobile location based marketing campaigns makes me feel that I am a unique customer. & 0.675 \\
\hline \multicolumn{2}{|l|}{ Permission } \\
\hline I am willing to give my mobile phone number to a company that practises mobile marketing. & 0.763 \\
\hline $\begin{array}{l}\text { I am willing to provide my background information (e.g. gender, age) to a company } \\
\text { practising } \\
\text { mobile marketing. }\end{array}$ & 0.766 \\
\hline I am willing to participate in mobile marketing activities. & 0.725 \\
\hline \multicolumn{2}{|l|}{ Perceived Behavior Control } \\
\hline $\begin{array}{l}\text { I find it important that I can choose the form of the mobile location based marketing } \\
\text { campaigns } \\
\text { (e.g. informing only, invitaing to participation etc.). }\end{array}$ & 0.739 \\
\hline $\begin{array}{l}\text { I find it important that I can easily control the number of mobile location based marketing } \\
\text { campaign messages I receive. }\end{array}$ & 0.768 \\
\hline $\begin{array}{l}\text { I find it important that I can easily stop mobile location based marketing campaign } \\
\text { messages. }\end{array}$ & 0.675 \\
\hline \multicolumn{2}{|l|}{ Personal Innovativeness } \\
\hline If I heard about a new information technology, I would look for ways to experiment with it. & 0.795 \\
\hline Among my peers, I am usually the first to try out new information technologies. & 0.664 \\
\hline I like to experiment with new information technologies. & 0.721 \\
\hline \multicolumn{2}{|l|}{ Mobile Marketing Experience } \\
\hline $\begin{array}{l}\text { When I was participating in Location Based Mobile Marketing Activities, I felt totally } \\
\text { captivated. }\end{array}$ & 0.817 \\
\hline $\begin{array}{l}\text { When I was navigating Location Based Mobile Marketing Activities, time seemed to pass } \\
\text { very quickly. }\end{array}$ & 0.855 \\
\hline $\begin{array}{l}\text { When I visited Location Based Mobile Marketing promotion page, nothing seemed to matter } \\
\text { to me. }\end{array}$ & 0.738 \\
\hline \multicolumn{2}{|l|}{ Perceived Ease of Use } \\
\hline $\begin{array}{l}\text { Learning to participate mobile location based marketing and promotional campaigns is easy } \\
\text { for me }\end{array}$ & 0.689 \\
\hline $\begin{array}{l}\text { It would be easy for me to become skillful at participate mobile location based marketing } \\
\text { and } \\
\text { promotional campaigns }\end{array}$ & 0.676 \\
\hline $\begin{array}{l}\text { My interactions with the mobile location based promotional campaigns are clear and } \\
\text { understandable }\end{array}$ & 0.660 \\
\hline
\end{tabular}


International Journal of Management and Information Technology

\begin{tabular}{|l|c|}
\hline Mobile location based marketing campaign messages are trustworthy & 0.802 \\
\hline Mobile location based marketing campaign messages have a good reputation & 0.702 \\
\hline Mobile location based marketing campaign systems are competent and effective. & 0.786 \\
\hline Perceived Privacy & 0.787 \\
\hline $\begin{array}{l}\text { Mobile location based marketing providers may keep my private information (including my } \\
\text { in a non-secure manner. }\end{array}$ & 0.821 \\
\hline $\begin{array}{l}\text { Mobile location based marketing providers may not take measures to prevent unauthorized } \\
\text { my personal information. }\end{array}$ & 0.764 \\
\hline $\begin{array}{l}\text { Mobile location based marketing providers may divulge my personal information to } \\
\text { unauthorized } \\
\text { parties without my consent }\end{array}$ & \\
\hline Intention & 0.835 \\
\hline I am willing to click location-based mobile marketing campaign invitations & 0.881 \\
\hline I expect to click location-based mobile marketing campaign invitations in the future & 0.662 \\
\hline $\begin{array}{l}\text { I expect that location-based mobile marketing systems would make everything easier in the } \\
\text { future }\end{array}$ & \\
\hline
\end{tabular}

Table 4.6: Exploratory Factor Analysis Results of Scales

\begin{tabular}{|c|c|c|c|c|c|c|c|c|c|c|}
\hline $\begin{array}{l}\text { Factors and } \\
\text { Related Items }\end{array}$ & $\begin{array}{l}\text { Perceived } \\
\text { Usefullne } \\
\text { ss }\end{array}$ & $\begin{array}{c}\text { Persona } \\
\text { I- } \\
\text { ization }\end{array}$ & $\begin{array}{l}\text { Permi } \\
\text { s- } \\
\text { sion }\end{array}$ & $\begin{array}{c}\text { Perceive } \\
d \\
\text { Behavio } \\
r \\
\text { Control }\end{array}$ & $\begin{array}{c}\text { Person } \\
\text { al } \\
\text { Innovat } \\
i- \\
\text { veness }\end{array}$ & $\begin{array}{c}\text { Mobile } \\
\text { Marketing } \\
\text { Experienc } \\
\mathrm{e}\end{array}$ & $\begin{array}{c}\text { Perceive } \\
\text { d } \\
\text { Ease } \\
\text { of Use }\end{array}$ & Trust & $\begin{array}{c}\text { Privac } \\
y\end{array}$ & $\begin{array}{c}\text { Intentio } \\
\mathbf{n}\end{array}$ \\
\hline $\begin{array}{l}\text { Cronbach's } \\
\text { Alpha }\end{array}$ & 0.890 & 0.848 & 0.834 & 0.812 & 0.807 & 0.876 & 0.759 & 0.844 & 0.866 & 0.865 \\
\hline $\begin{array}{l}\text { Kaiser Meyer } \\
\text { Olkin Measure } \\
\text { of } \\
\text { Sampling } \\
\text { Adequacy: }\end{array}$ & 0.743 & 0.697 & 0.723 & 0.705 & 0.690 & 0.717 & 0.695 & 0.714 & 0.731 & 0.670 \\
\hline $\begin{array}{l}\text { Bartlett's Test } \\
\text { of } \\
\text { Sphericity } \\
(p: 0.000<0.05) \text { : }\end{array}$ & 628.633 & 544.670 & $\begin{array}{l}421.51 \\
6\end{array}$ & 373.277 & 382.128 & 598.558 & 264.706 & $\begin{array}{c}465.63 \\
0\end{array}$ & $\begin{array}{l}528.68 \\
5\end{array}$ & 648.518 \\
\hline $\begin{array}{l}\% \text { of total } \\
\text { Variance } \\
\text { Explained: }\end{array}$ & 82.017 & 77.847 & 75.128 & 72.733 & 72.672 & 80.345 & 67.499 & 76.335 & 78.924 & 79.296 \\
\hline
\end{tabular}

\subsubsection{Confirmatory Factor Analysis (CFA) On Main Data with Amos}

Variable scores figured in the CFA connection regularly utilize comparative techniques as portrayed here.

Structural Equation Modeling (SEM) is used to determine the Fit Index:

p-value: If $p<0.05$, the proposed model needs to be dismissed. In the case that $p$-quality is $>0.05$, the proposed model will be accepted.

CMIN/DF: Relative chi-square, also called typical chi-square, is the chi-square fit file isolated by degrees of flexibility, trying to make it less reliant on test size. There is great model fit if CMIN/DF is not exactly or equivalent to 5.

RMSEA: Root mean square blunder of estimation, there is a great model fit if RMSEA is between 0.05 - 0.10.

GFI: GFI should be higher than 0.90 to show solid match. An estimation of 1 demonstrates aperfect fit. GFI has a tendency to be bigger as test size increments.

NFI: NFI (normed fit file, also called the Bentler-Bonett normed fit index, DELTA1), 1 = perfect fit. NFI values above 0.95 are great; somewhere around 0.90 and 0.95 are adequate, and below 0.90 shows a need to reconsider the model. 
International Journal of Management and Information Technology CFI: (near fix record), near 1 demonstrates a solid match, $>0.9$ or near 0.95 shows solid match, by tradition, CFI should be equivalent to or more prominent than 0.90 to acknowledge the model.

RMR (root mean square residual), the littler the RMR, the better the model. A RMR of zero shows a flawless fit. The nearer the RMR to 0 for a model being tried, the better the model fit. RMR smaller than 0,10 shows solid match.

AGFI (balanced GFI), AGFI alters the GFI for level of opportunity, bringing about lower values for models with more parameters. AGFI should likewise be no less than 0.90; near 1 demonstrates solid match.

Hence, in this research, confirmatory factor analyses were presented by referencing aforementioned fit index indicators. Indicators have been taken into consideration as the basis of numerical comparisons .

Results of the AMOS analysis interpreted as CR>1.96 for a regression path is significant at 0.05 or better $(p<0.05)$ and the three asterisks on the table show the significance below 0.001. In Table 4.7, it can be observed that regression weights are proving the model fit in AMOS results; furthermore in the same table as AMOS output, the critical ratio and the significance of path coefficients are presented.

Table 4.7: Standardized Regression Weights of AMOS

\begin{tabular}{|c|c|c|c|c|c|c|c|}
\hline & & & Estimate & S.E. & C.R. & $P$ & Label \\
\hline ZPEU & $<---$ & ZINOV & .366 & .048 & 7,555 & 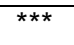 & par_1 \\
\hline ZUSEFULNESS & $<---$ & ZPERS & .595 & .042 & 14,204 & ${ }^{* * *}$ & par_3 \\
\hline ZTRUST & $<--$ & ZPEU & .458 & .043 & 10,679 & *** & par_2 \\
\hline ZTRUST & $<--$ & ZUSEFULNESS & .344 & .042 & 8,103 & *** & par_4 \\
\hline ZPERMISSION & $<--$ & ZEXPERIENCE & .683 & .038 & 18,031 & *** & par_7 \\
\hline ZINT & $<--$ & ZTRUST & .754 & .069 & 10,904 & 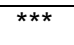 & par_5 \\
\hline ZINT & $<--$ & ZPERMISSION & .144 & .052 & 2,789 & 0.05 & par_6 \\
\hline
\end{tabular}

As shown in Table 4.8, there is good model fit (CMIN/DF is 2.162 less than 5). Also there is adequate fit since RMSEA is 0.057 ,i.e. less than 0.08. NFI values above 0.95 are good and here NFI is 0.992 . CFI is 0.996 , very close to 1 and indicates a very good fit. RMR (root mean square residual); the smaller the RMR, the better the model. RMR smaller than 0.10 indicates good fit. Here, RMR value is 0.18 and indicates an acceptable fit.GFI value is 0.991 and indicates good fit. AGFI is 0.948 (close to 0.90, indicating good fit).

SEM results of AMOS prove that the proposed model is valid and reliable. In this study, AMOS has been used to test the relationships of the structural model. Multivariate techniques, certain multivariate assumptions have been tested.

Linearity and multi-collinearity tests have been performed and investigated in the next section to ensure that the measurement model can be tested using structural equation modeling.

Table 4.8 CFA Results of AMOS

\begin{tabular}{|l|c|c|c|}
\hline MODEL & Default & Saturated & Independence \\
\hline NPAR & 30 & 36 & 8 \\
\hline CMIN & 12,974 & .000 & 1611.108 \\
\hline $\mathrm{P}$ & .043 & & .000 \\
\hline CMIN/DF & 2,162 & & 57,540 \\
\hline RMSEA & .057 & & .395 \\
\hline LO 90 & .009 & & .378 \\
\hline HI 90 & .099 & & .411 \\
\hline PCLOSE & .343 & & .000 \\
\hline NFI Delta1 & .992 & 1,000 & .000 \\
\hline RFI rho 1 & .962 & & .000 \\
\hline IFI Delta2 & .996 & 1,000 & .000 \\
\hline TLI rho2 & .979 & & .000 \\
\hline
\end{tabular}




\begin{tabular}{|l|c|c|c|} 
CFI & .996 & 1,000 & .000 \\
\hline RMR & .018 & .000 & .476 \\
\hline GFI & .991 & 1,000 & .328 \\
\hline AGFI & .948 & & .136 \\
\hline PGFI & .165 & & .225 \\
\hline
\end{tabular}

In order to examine for linearity, several bivariate scatterplots were generated and examined. AMOS only tests linear relationships whereas a scatterplot matrix reveals normal distributions and linear relationships among variables. Linearity is the proof of relationship between variables showing the association therebetween[30].

Multi-collinearity (also collinearity) is a phenomenon in which two or more predictor variables in a multiple regression model are highly correlated, meaning that one can be linearly predicted from the others with a substantial degree of accuracy [47].

The Variance Inflation Factor (VIF) and tolerance are both generally utilized measures of the level of multi-collinearity of the independent variable with the other free variables in a regression model [65].

As shown in Table 4.16, there is no multi-collinearity for the set of constructs tested since tolerance values are below the cut-off point of 0.90 and variance inflation factors (VIF) are less than 10. Hair et al.[29]suggest that a VIF of less than 10 are indicative of unimportant collinearity.

Table 4.9: Linearity Test Results

\begin{tabular}{|c|c|c|c|c|c|}
\hline \multicolumn{2}{|c|}{ Variable } & \multicolumn{3}{|c|}{ Model Summary } & \multirow[b]{2}{*}{ Result } \\
\hline Independent & Dependent & R Square & $\mathbf{F}$ & Sig. & \\
\hline Permission & $\begin{array}{l}\text { Intention to participate } \\
\text { in } \\
\text { Location-Based } \\
\text { Marketing }\end{array}$ & 0.471 & 321.829 & 0.000 & Linear \\
\hline Perceived Trust & $\begin{array}{l}\text { Intention to participate } \\
\text { in } \\
\text { Location-Based } \\
\text { Marketing }\end{array}$ & 0.417 & 258.504 & 0.000 & Linear \\
\hline $\begin{array}{l}\text { Mobile Marketing } \\
\text { Experience }\end{array}$ & Permission & 0.471 & 322.750 & 0.000 & Linear \\
\hline $\begin{array}{l}\text { Perceived } \\
\text { Usefulnes }\end{array}$ & Perceived Trust & 0.352 & 196.494 & 0.000 & Linear \\
\hline $\begin{array}{l}\text { Perceived Ease of } \\
\text { Use }\end{array}$ & Perceived Trust & 0.418 & 260.404 & 0.000 & Linear \\
\hline Personalization & Perceived Usefulness & 0.347 & 192.586 & 0.000 & Linear \\
\hline $\begin{array}{l}\text { Personal } \\
\text { Innovativeness }\end{array}$ & Perceived Ease of Use & 0.137 & 57.500 & 0.000 & Linear \\
\hline
\end{tabular}

Table 4.10: Collinearity Test Result of Intention to Participate LBM

\begin{tabular}{|l|c|c|}
\hline \multirow{2}{*}{ Model } & \multicolumn{2}{c|}{ Collinearity Statistics } \\
\cline { 2 - 3 } & Tolerance & VIF \\
\hline Permission & 0.438 & 2.282 \\
\hline Perceived Privacy & 0.870 & 1.149 \\
\hline Perceived Trust & 0.410 & 2.436 \\
\hline $\begin{array}{l}\text { Mobile Marketing } \\
\text { Experience }\end{array}$ & 0.352 & 2.837 \\
\hline Perceived Usefulness & 0.442 & 2.261 \\
\hline
\end{tabular}


International Journal of Management and Information Technology

\begin{tabular}{|l|c|c|} 
Perceived Ease of Use & 0.480 & 2.082 \\
\hline Personalization & 0.512 & 1.952 \\
\hline Personal Innovativeness & 0.766 & 1.305 \\
\hline
\end{tabular}

AMOS analysis proved that 7 out of 10 constructs created a valid and a reliable model. In the model,as a result ofconfirmatory factor analysis with AMOS, perceived behavior control and perceived privacy were not included.

Figure 4.1 demonstrates the output of the model fit. According to this model, 7 constructs affect the intention to participate inlocation-based marketing campaigns and offerings directly or indirectly.

$\mathrm{H} 1$ : Perceived usefulness has a positive effect on perceived trust.

In Table7, there is a path in SEM diagram from perceived usefulness to perceived trust, thus $\mathrm{H} 1$ is accepted, meaning that perceived usefulness positively influences perceived trust.

This hypothesis is accepted with a CR value of $8.103(>1.96)$ that is statistically significant $\left({ }^{* * *}\right)$ with the confidence level below 0.001 . Constructs have a positive relationship as understood from the regression coefficient of 0.344 .

H2: Personalization has a positive effect on perceived trust.

According to the standardized regression weights of AMOS (Table 4.7)there is no path in SEM diagram from personalization to perceived trust,therefore $\mathrm{H} 2$ is rejected, meaning that personalization does not directly influence perceived trust. However, personalization is still one of the important constructs in the model empirically and further to the in-depth interviews, it has been proven that this construct has a direct positive effect to perceived usefulness.

H3: Perceived ease of use has a positive effect on perceived trust.

There is a path in SEM diagram from perceived ease of use to perceived trust, therefore $\mathrm{H} 3$ is accepted, meaning that perceived ease of use directly influences perceived trust. This hypothesis is accepted with a CR value of 10.679 (>1.96) and is statistically significant,belowthe $0.001(<0.05)$ confidence level. Constructs have positive relationships as understood from the regression coefficient of 0.458 .

H4: Perceived trust has a positive effect on intention to participate in location-based mobile marketing.

Further, AMOS CPA analysis standardized regression weights table of AMOS (Table 4.7) proved that there is a path in SEM diagram from perceived trust to intention to participate in location-based mobile marketing, therefore $\mathrm{H} 4$ is accepted, meaning that perceived trust has a positive effect on intention to participate in location-based mobile marketing. This hypothesis is accepted with a CR value of $10.904(>1.96)$ and is statistically significant,below the $0,001(<0.05)$ confidence level. Constructs have positive relationships as understood from the regression coefficient of 0.754 .

H5: Perceived privacy has a positive effect on intention to participate in the location-based mobile marketing.

According to the standardized regression weights of AMOS (Table 4.7), there is no path in SEM diagram from personalization to perceived trust, therefore $\mathrm{H} 5$ is rejected, meaning that perceived privacy has no direct positive effect on intention to participate in location-based mobile marketing.

H6: Perceived behavior control has a positive effect on permission.

In the SEM diagram and with the proof of AMOS standardized regression weight table (Table 4.7), the construct of perceived behavioral control is declinedfrom the model and therefore $\mathrm{H} 6$ is rejected, meaning that perceived behavioral control has no positive effect on permission.

H7: Mobile marketing experience has a positive effect on permission.

There is a path in SEM diagram and AMOS standardized regression weight table (Table 4.7) from mobile marketing experience to permission, therefore $\mathrm{H} 7$ is accepted, meaning that mobile marketing experience directly influences permission.

This hypothesis is accepted with a CR value of 18.031 (>1.96) and is statistically significant below the $0.001(<0.05)$ confidence level. Constructs have positive relationships as understood from the regression coefficient of 0.683 .

H8: Permission has a positive effect on intention to participate in the location-based mobile marketing.

Standardized regression weights of AMOS (Table 4.7) shows that there is a path in SEM diagram from permission to intention, therefore $\mathrm{H} 8$ is accepted, meaning that perceived usefulness directly influences intention.

This hypothesis is accepted with a CR value of $2.789(>1.96)$ and is statistically significant,below the $0.005(<0.05)$ confidence level. Constructs have positive relationships as understood from the regression coefficient of 0.144 .

H9: Personal innovativeness has a positive effect on intention to participate in the location-based mobile marketing.

3014 | P a g e

Nove m b e 2016 council for Innovative Research w w w. cir w o r ld. co m 
International Journal of Management and Information Technology According to the standardized regression weights of AMOS (Table 4.7), there is no path in SEM diagram from Personal Innovativeness to intention to participate in the location-based mobile marketing, therefore $\mathrm{H} 9$ is rejected,meaning that personal innovativeness does not directly influence intention to participate in the location-based mobile marketing.

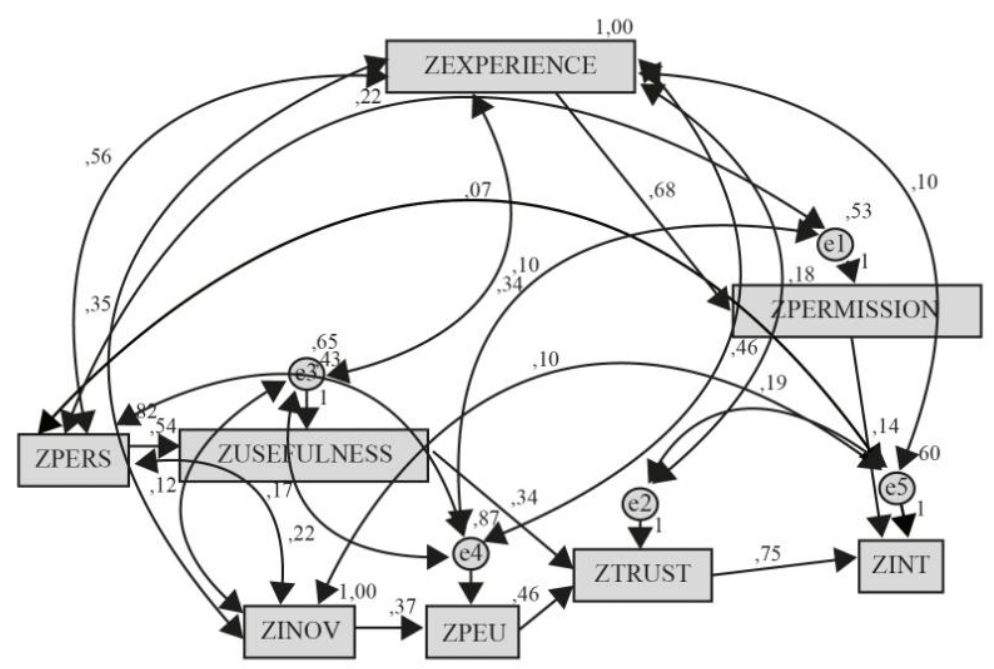

Figure 4.2: AMOS Output of Main Data Fit Model

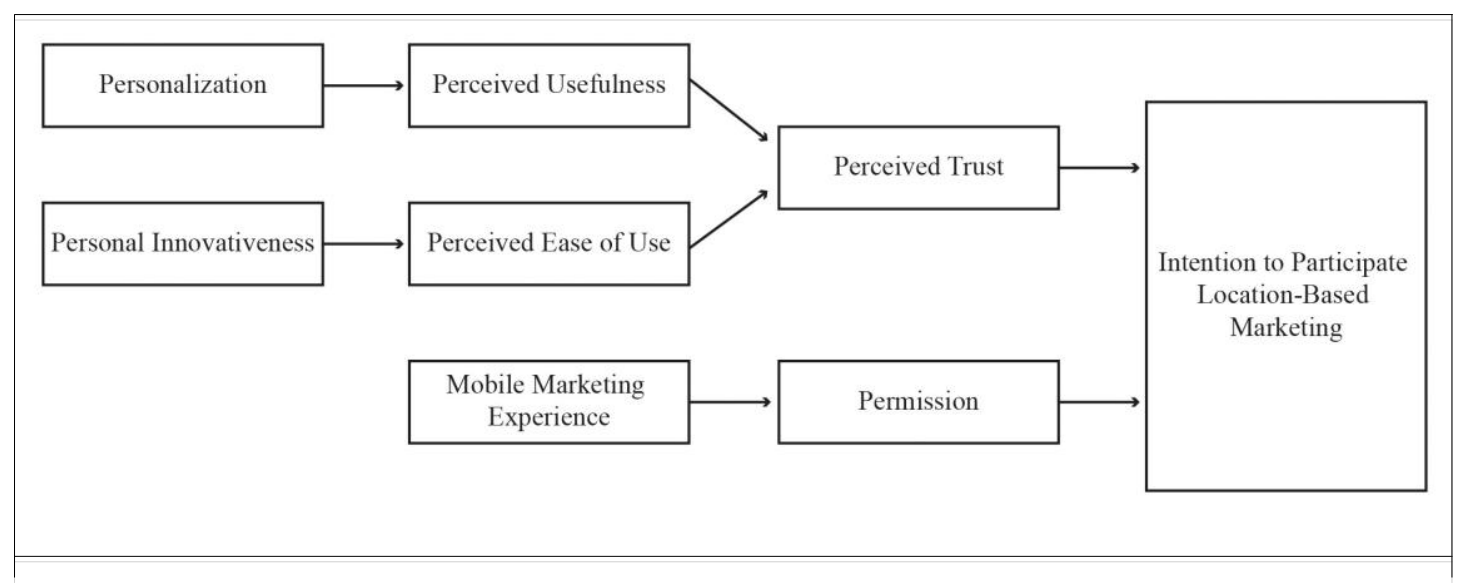

Figure 4.3: Fit Model

\section{CONCLUSION}

With the advances in technology, every day different ways to reach customers are created. Location-based marketing is a developing marketing channel which deserves to be investigated thoroughly. As a result the factors affecting the adoption to location-based marketing have become interesting marketing phenomena that need to be explored. This article provides directions tocompanies and marketing professionals in different sectors in Turkey to understand the theoretical background of location-based mobile marketing and to make their decisions by considering different factors affecting the success of location-based mobile marketing activities.

Consumers in Turkey are using various mobile services in their daily lives and they have a quick adoption to use different technologies provided by mobile application developers and mobile phone vendors. Marketers have been using this mobile potential of Turkish consumers for years and this article contributes to the mobile marketing knowledge by concentrating on location information.

The findings of the article focus on the adoption behavior of Turkish local mobile consumers to location-based marketing. Direct or indirect influential factors may certainly be different for the developed, underdeveloped or emerging markets.

One of the distinct contributions of this article is to encourage mobile technology use in the marketing ecosystem. Since it is difficult to evaluate the efficiency of the marketing channel, the speed of technological developments can sometimes affect the use of technology in marketing unfavorably. Disclosure of the important factors to be considered during the preparation of mobile marketing programs encourages marketers to use location-based marketing. 


\subsection{Theoretical Implications}

After having examined the previous models presented in the literature, nine constructs affecting the adoption to locationbased mobile marketing have been suggested to be tested in the model. The structural equations model testing proved that seven out of these nine constructs are significant and affect the participation in location-based marketing by consumers. These factors are: perceived usefulness, perceived ease of use, personalization, perceived trust, permission, mobile marketing experience and personal innovativeness. With the model of this research it has been proven that the set of factors mentioned above has direct or indirect relations with intention to participate mobile location based marketing activities in emerging countries. When we look at similar researches for developed countries in the literature, we find that the two constructs of privacy and perceived behavior control, which we see directly affect adaptation to mobile locationbased marketing, have no direct or indirect effect on emerging countries.

Davis (1989) defined perceived usefulness as the degree to which a person believes that using a particular system would enhance his/her performance. It is critically important for marketers to recognize what is relevant or meaningful or both for their customers and to think of usefulness as the first lever to develop more positive attitudes towards mobile marketing and increase mobile activity. This finding proves that in case of an increase in the perception of usefulness with regard to any location-based marketing activity, perception of trust will increase and finally mobile consumers will have more intention to participate in the location-based mobile marketing activity.

Considering the general usage of perceived usefulness in conjunction with perceived ease of use as an indicator of new innovation affirmation, literature surveys demonstrated that perceived usefulness has been used as an important construct affecting the adoption to mobile and internet-based services, for instance, m-payment (Ha et al., 2012). These studies affirmed the solid impact of perceived usefulness on client response. Zarmpou et al. (2012) additionally affirmed the solid impact of perceived usefulness on the selection of mobile marketing systems. Wu and Wang (2005) also claim that perceived usefulness has a direct positive effect on intention to utilize $m$-trade.

Past studies have supported a positive relationship between perceived ease of use and trust (Schepers and Wetzels, 2007) and between usability and expectation (Zhang et al., 2008).In this study as well, perceived ease of use has been found to have a direct positive effect on perceived trust. The findings reveal that regarding the adoption of Turkish mobile consumers to location-based marketing activities, an increase on perceived ease of use will trigger an increase in perceived trust and this will in turn create more intention in the mobile consumer to participate in the location-based marketing activities.

As demonstrated by Greenville (2005), one of the essential reasons affecting the mobile advertising negatively is the obvious absenceof trust in mobile clients. Consequently, without a doubt, perceived trust has an impact on intention to participate in location-based mobile marketing and since, according to the analysis, there is a direct positive relationship between two constructs, our hypothesis is proven. When the customers perceived trust to the brand and the location based mobile marketing campaign of the brand is high their intention is stronger to join the mobile location-based marketing activity.

As the participants belong to a well-educated group (university degree and above $95,88 \%$ ), their quest for new things is expected to be higher than the other groups.

In this research by far, most of the subjects had mobile Internet experiences that indicated they had a specific level of comprehension of mobile services and they were interested in mobile marketing efforts. Experience can be acquired only through exposure to mobile marketing products and services. Consumers who have never bought or used mobile marketing products and services are more risk-averse than those who have bought or used before (Foxall, 2002).In the proposed model, mobile marketing experience has proven to have a positive effect on permission. In case a person uses mobile products and services regularly and has an experience on mentioned products or services, it can be assumed that he or she is more willing to provide permission.

\subsection{Managerial Implications}

This article attempts to offer insight to marketers in order to use location-based mobile marketing more effectively in their marketing mix. Findings of the research imply that, in Turkey, if a marketer includes location-based marketing in the marketing program should consider trust and permission as two very strong factors affecting the success of the program. These two factors directly affect the adoption to location-based marketing.

To be successful, a location-based marketing campaign needs to enhance trust in and take permissions from potential consumers in advance. Besides, marketers should take usefulness and ease of use as strong influential factors since these factors affect trust. If consumers are not convinced on the usefulness of the campaign or the campaign architecture, the trust in the marketing campaign will decrease.It also can provide practical guidance for managers carrying out mobile marketing activities in Turkey. The analysis showed that consumer innovativeness, personalization, permission, perceived ease of use, mobile marketing experience, perceived usefulness, and perceived trust had direct or indirect impacts on the intention of consumers to participate in location-based mobile marketing.

Findings in this article also disclose several problems that managers need to examine related to the growth of mobile marketing practice among consumers. In markets such as Turkey, there are important consumer concerns that have led to industrial regulation of mobile marketing practices and privacy policies. Developing strategies to get consumers join

$\mathbf{3 0 1 6}$ | P a g e
Nove m b e r 2016 

location-based mobile marketing activities and participate in the commercial mobile space, managers will need to understand the importance of privacy issues across different cultures.

It will be important for marketers to consider pros and cons of carrying customer value to consumers in the mobile marketing context. Important methods should be developed for permission-based participation in the mobile marketing environment by considering trust, usefulness, personalization, ease of use, mobile experience and privacy; namely marketing professionals should aim to finely target individuals with value-based content, features, and applications that suit their needs.

Incentive-based model will also be an interesting way to attract consumers in which consumers agree to accept the advertising sent to them in return for promotion and possibly for mobile content or application. Managers will need to highlight privacy, permission and trust models or incentive-based models for adoptive participation in location-based mobile marketing programs and promotions.

\subsection{Limitations and Suggestions for Future Research}

Mobile technologies are rapidly changing and may be altered in nature. Concurrently mobile consumers learn and their behavior and adoptioncriteria differ in time. Mobile location-based marketing should be examined on a longitudinal basis and the quest should be repeated to see the changes occurring in both technological and marketing environments. The study constitutes a starting point for further examination of location-based marketing in emerging countries like Turkey.

One of the limitations of the study is that the education level of people selected with convenience sampling is high. It may be interesting to see whether the factors affecting the participation level in location-based marketing will change in different education and age structures. If repeated in other emerging countries, the study may reveal cross-cultural similarities and differences.

Especially brands providing mobile applications to their customers, analytic tools embedded in the mobile internet sites of these brands and GSM operators collect very important data which could be a valuable source for future research of location-based marketing. Asmentioned, contemporary tools that are allowing marketers to make detailed behavior analysis by using real data may give a broader idea about the success factors of location-based mobile marketing.

Hence, to be able to extend this research to a broader customer audience, future research about location-based marketing can be carried out by using data gathered from these sources and should provide empirical analysis about the participants. Furthermore, future studies should consider and subsequently test both the direct effect and possible moderating effects of this type of mobile marketing campaigns.

\section{REFERENCES}

\section{Books}

[1] Hair, J. F., Wolfinbarger, M. F., Ortinau, D. J., \& Bush, R. P. (2008). Essentials of marketing research. McGrawHill/Higher Education.

[2] Pine, B. J., Peppers, D., \& Rogers, M. (1995). Do you want to keep your customers forever? Harvard Business Press.

[3] Rietveld, T., \& Van Hout, R. (1993). Statistical techniques for the study of language and language behaviour. Walter de Gruyter.

[4] Varnali, K., Toker, A., \&Yilmaz, C. (2011). Mobile marketing: Fundamentals and strategy. McGraw-Hill.

\section{Periodicals}

[5] Bamba, F., \& Barnes, S. J. (2007). SMS advertising, permission and the consumer: a study. Business Process Management Journal, 13(6), 815-829.

[6] Barnes, S. J., \&Scornavacca, E. (2004). Mobile marketing: the role of permission and acceptance. International Journal of Mobile Communications, 2(2), 128-139.

[7] Barnes, S. J. (2003). Location-based services: the state of the art. E-Service, 2(3), 59-70.

[8] Barutcu, S. (2007). 'Attitudes towards mobile marketing tools: A study of Turkish consumers. Journal of Targeting,' Measurement and Analysis for Marketing, 16, 26-38.

[9] Barutcu, S. (2008). Consumers' attitudes towards mobile marketing and mobile commerce in consumer markets. Ege Academic Review, 8(1), 15-32.

[10] Basheer, A. A. A., \& Ibrahim, A. A. (2010). Mobile marketing: Examining the impact of trust, privacy concern and consumers' attitudes on intention to purchase. International journal of business and management, 5(3), 28.

[11] Bauer, H. H., Barnes, S. J., Reichardt, T., \& Neumann, M. M. (2005). Driving consumer acceptance of mobile marketing: A theoretical framework and empirical study. Journal of electronic commerce research, 6(3), 181-192.

[12] Beresford, A. R., \&Stajano, F. (2004, March). Mix Zones: User Privacy in Location-aware Services. In PerCom Workshops (pp. 127-131). 
International Journal of Management and Information Technology

[13] Bigne, E., Ruiz, C., \&Sanz, S. (2005). The impact of internet user shopping patterns and demographics on consumer mobile buying behaviour. Journal of Electronic Commerce Research, 6(3), 193-210.

[14] Bollen, K. A. (1989). A new incremental fit index for general structural equation models. Sociological Methods \& Research, 17(3), 303-316.

[15] Campbell, D. T., \& Fiske, D. W. (1959). Convergent and discriminant validation by the multitrait-multimethod matrix. Psychological bulletin, 56(2), 81.

[16] Comrey, A. L., \& Lee, H. B. (1973). A first course in factor analysis.

[17] Consolvo, S., Smith, I. E., Matthews, T., LaMarca, A., Tabert, J., \&Powledge, P. (2005, April). Location disclosure to social relations: why, when, \& what people want to share. In Proceedings of the SIGCHI conference on Human factors in computing systems (pp. 81-90). ACM.

[18] Craig, C. S., \& Douglas, S. P. (2000). Configural advantage in global markets. Journal of international Marketing, 8(1), 6-26.

[19] Davis, Fred D. 1989. Perceived usefulness, perceived ease of use, and user acceptance of information technology. MIS Quarterly 13:319-340

[20] Dholakia, U. M. (2000). Temptation and resistance: an integrated model of consumption impulse formation and enactment. Psychology \& Marketing, 17(11), 955-982.

[21] Foxall, G.R. (2002), Consumer Behaviour Analysis: Critical Perspectives, Routledge, London and New York, NY.

[22] Grant, I., \&O'Donohoe, S. (2007). Why young consumers are not open to mobile marketing communication. International Journal of Advertising, 26(2), 223-246.

[23] Greenville, M. (2005), "Stats \& research: big brands still won't use mobile", 160Characters, available at: www.160characters.org/news.php?action V4 view\&nidV4 1647 (accessed 26 October 2006).

[24] Guadagnoli, E., \&Velicer, W. F. (1988). Relation to sample size to the stability of component patterns. Psychological bulletin, sychological

[25] Ha, K. H., Canedoli, A., Baur, A. W., \& Bick, M. (2012). Mobile banking-insights on its increasing relevance and most common drivers of adoption. Electronic Markets, 22(4), 217-227.

[26] Habing, B. (2003). Exploratory factor analysis. University of South Carolina-October, 15, 2003.

[27] Haghirian, P., \& Inoue, A. (2007). An advanced model of consumer attitudes towardadvertising on the mobile internet. International Journal of Mobile Communications,5(1), 48-67.

[28] Haghirian, P., Madlberger, M.,Tanuskova, A. (2005, January). Increasing advertising value of mobile marketing-an empirical study of antecedents. InSystem Sciences, 2005. HICSS'05. Proceedings of the 38th Annual Hawaii International Conference on (pp. 32c-32c). IEEE.

[29] Hair Jr, J. F., Anderson, R. E., Tatham, R. L., \& William, C. (1995). Black. 1995. Multivariate data analysis with readings, 4.

[30] Hair, J. F. (2006). Multivariate data analysis-6/E.

[31] Harris, P., Rettie, R., \& Kwan, C. C. (2005). Adoption and usage of M-commerce: A crosscultural comparison of Hong Kong and the United Kingdom. Journal of Electronic Commerce Research, 6(3), 210-225

[32] He, Junhong, Depeng Zhang, and Yixia Mao. An empirical study on consumer intention to participate in mobile marketing in China. Journal of Business Management and Economics. 4.7 (2013): 156-165.

[33] Hirunyawipada, T., \&Paswan, A. K. (2006). Consumer innovativeness and perceived risk: implications for high technology product adoption. Journal of Consumer Marketing, 23(4), 182-198.

[34] Ho, S. Y. (2012). The effects of location personalization on individuals' intention to use mobile services. Decision Support Systems, 53(4), 802-812.

[35] Hoffman, D. L., \& Novak, T. P. (2009). Flow online: lessons learned and future prospects. Journal of Interactive Marketing, 23(1), 23-34.

[36] Hogarty, K. Y., Hines, C. V., Kromrey, J. D., Ferron, J. M., \& Mumford, K. R. (2005). The quality of factor solutions in exploratory factor analysis: The influence of sample size, communality, and overdetermination. Educational and Psychological Measurement, 65(2), 202-226.

[37] Hu et al., 1999. P.J. Hu, P.Y.K. Chau, O.R.L. Sheng, K.Y. Tam Examining the technology acceptance model using physician acceptance of telemedicine technology. Journal of Management Information Systems, 16 (2) (1999), pp. $91-112$ 
[38] Huang, L., Hsieh, Y., \& Chang, S. E. (2011). The effect of consumer innovativeness on adoption of location-based services.

[39] Im, H., \& Ha, Y. (2013). Enablers and inhibitors of permission-based marketing: A case of mobile coupons. Journal of Retailing and Consumer Services, 20(5), 495-503.

[40] Jayawardhena, Chanaka, et al. Antecedents to permission based mobile marketing: an initial examination. European Journal of Marketing 43.3/4 (2009): 473-499.

[41] Johnson, V., Torres, R., Phillips, B., \&Rahnamaee, A. (2013). Continued Usage of Location-Based Services: Privacy Risk Impact on Motivation and Adoption.

[42] Junglas, I. A., Johnson, N. A., \&Spitzmüller, C. (2008). Personality traits and concern for privacy: an empirical study in the context of location-based services. European Journal of Information Systems, 17(4), 387-402.

[43] Kalinic, Z., \&Marinkovic, V. (2015). Determinants of users' intention to adopt m-commerce: an empirical analysis. Information Systems and e-Business Management, 1-21.

[44] Kaplan, A. M. (2012). If you love something, let it go mobile: Mobile marketing and mobile social media 4x4. Business horizons, 55(2), 129-139.

[45] Karjaluoto, Heikki, et al. Exploring gender influence on customer's intention to engage permission-based mobile marketing. Electronic markets 18.3 (2008): 242-259.

[46] Kautonen, T., Karjaluoto, H., Jayawardhena, C., \&Kuckertz, A. (2007). Permission-based mobile marketing and sources of trust in selected European markets. Journal of Systems and Information Technology, 9(2), 104-123.

[47] Kleijnen, M., De Ruyter, K., \&Wetzels, M. (2004). Consumer adoption of wireless services: discovering the rules, while playing the game. Journal of Interactive Marketing, 18(2), 51-61.

[48] Kotler, P., \& Armstrong, G. (2008). Prinsip-prinsippemasaran. Jakarta: PenerbitErlangga.

[49] Krejcie, R. V., \& Morgan, D. W. (1970). Determining sample size for research activities. Educpsychol meas.

[50] Kumar, T. K. (1975). Multicollinearity in regression analysis. The Review of Economics and Statistics, 57(3), 36566.

[51] Lee, T. The impact of perceptions of interactivity on customer trust and transaction intentions in mobile commerce. Journal of Electronic Commerce Research 6.3 (2005): 165-180.

[52] Lee, R., Murphy, J., \& Neale, L. (2009). The interactions of consumption characteristics on social norms. Journal of Consumer Marketing, 26(4), 277-285.

[53] Lehrer, C., Constantiou, I., \& Hess, T. (2011). A CognitiveProcesses Analysis OfIndividuals'use Of Location-Based Services.

[54] Leppaniemi, M., Karjaluoto, H., and Salo, J. (2004), The success factors of mobile advertising value chain. Ebusiness Review IV, pp. 93-97.

[55] Leppaniemi, M., \&Karjaluoto, H. (2005). Factors influencing consumers' willingness to accept mobile advertising: a conceptual model. International Journal of Mobile Communications, 3(3), 197-213.

[56] Leppaniemi, M., \&Karjaluoto, H. (2008). Mobile marketing: From marketing strategy to mobile marketing campaign implementation. International Journal of Mobile Marketing, 3(1), 50-61.

[57] Li, K., \& Du, T. C. (2012). Building a targeted mobile advertising system for location-based services. Decision Support Systems, 54(1), 1-8.

[58] Li, J. (2009, May). Theoretical model of consumer acceptance: in the view of website quality. In 2009 International Conference on E-Business and Information System Security (pp. 1-4). IEEE.

[59] Li, Y. M., \&Yeh, Y. S. (2010). Increasing trust in mobile commerce through design aesthetics. Computers in Human Behavior, 26(4), 673-684.

[60] Lin, T. T., Paragas, F., Goh, D., \& Bautista, J. R. (2016). Developing location-based mobile advertising in Singapore: A socio-technical perspective. Technological Forecasting and Social Change, 103, 334-349.

[61] Malhotra, R. K., \&Indrayan, A. (2010). A simple nomogram for sample size for estimating sensitivity and specificity of medical tests. Indian journal of ophthalmology, 58(6), 519..

[62] Merisavo, M., Kajalo, S., Karjaluoto, H., Virtanen, V., Salmenkivi, S., Raulas, M., \&Leppäniemi, M. (2007). An empirical study of the drivers of consumer acceptance of mobile advertising. Journal of Interactive Advertising, 7(2), 41-50.

[63] Nowak, G.J., S.A. Shamp, B.A. Hollander, and G.T. Cameron, "Interactive media: A means for more meaningful advertising?", In D.W. Schumann and E. Thorson, Advertising and the World Wide Web. Lawrence Erlbaum, 1999. 
International Journal of Management and Information Technology

[64] Nysveen, H., Pedersen, P. E., \&Thorbjørnsen, H. (2005). Intentions to use mobile services: antecedents and crossservice comparisons. Journal of the Academy of Marketing Science, 33(3), 330-346.

[65] O'Brien, R. M. (2007). A caution regarding rules of thumb for variance inflation factors. Quality \& Quantity, 41(5), 673-690.

[66] Oh, L. B., \&Xu, H. (2003). Effects of multimedia on mobile consumer behavior: An empirical study of location-aware advertising.

[67] Okazaki, S., \& Mendez, F. (2013). Perceived ubiquity in mobile services. Journal of Interactive Marketing, 27(2), 98-111.

[68] Okazaki, S. (2007). Exploring gender effects in a mobile advertising context: on the evaluation of trust, attitudes, and recall. SexRoles, 57(11), 897-908.

[69] Pagani, M. (2004). Determinants of adoption of third generation mobile multimedia services. Journal of interactive marketing, 18(3), 46-59.

[70] Persaud, A., \&Azhar, I. (2012). Innovative mobile marketing via smartphones: are consumers ready? Marketing Intelligence \& Planning, 30(4), 418-443.

[71] Peterson, R. A. (1994). A meta-analysis of Cronbach's coefficient alpha. Journal of consumer research, 21(2), 381391.

[72] Pura, M. (2005). Linking Perceived Value and Loyalty in Location-based Mobile Services. Managing Service Quality, 15 (6), 509-538.

[73] Rao, B., \&Minakakis, L. (2003). Evolution of mobile location-based services. Communications of the ACM, 46(12), 61-65.

[74] Roca, Juan Carlos, Juan José García, and Juan José de la Vega. The importance of perceived trust, security and privacy in online trading systems. Information Management \& Computer Security 17.2 (2009): 96-113.

[75] Rogers Everett, M. (1995). Diffusion of innovations. New York, 12.

[76] Rohm, A. J., Gao, T. T., Sultan, F., \&Pagani, M. (2012). Brand in the hand: A cross-market investigation of consumer acceptance of mobile marketing. Business Horizons, 55(5), 485-493.

[77] Salo, J. \&Tähtinen J.(2005). Retailer Use of Permission-Based Mobile Advertising. In: Advances in Electronic Marketing, 139-155

[78] Sapnas, K. G., \& Zeller, R. A. (2002). Minimizing sample size when using exploratory factor analysis for measurement. Journal of nursing measurement, 10(2), 135-154.

[79] Scharl, A., Dickinger A., Murphy, J. (2005) Diffusion and success factors of mobile marketing Electronic Commerce Research and Application, Vol. 4, (2), 159-173.

[80] Shankar, V., \&Balasubramanian, S. (2009). Mobile marketing: a synthesis and prognosis. Journal of Interactive Marketing, 23(2), 118-129.

[81] Schepers, J., \&Wetzels, M. (2007). A meta-analysis of the technology acceptance model: Investigating subjective norm and moderation effects. Information \& management, 44(1), 90-103.

[82] Schultz, D. E., \& Bailey, S. E. (2000). Customer/brand loyalty in an interactive marketplace. Journal of Advertising Research, 40(3), 41-52.

[83] Siau, K., \&Shen, Z. (2003). Building customer trust in mobile commerce. Communications of the ACM, 46(4), 9194.

[84] Stafford, T. F., \&Gillenson, M. L. (2003). Mobile commerce: what it is and what it could be. Communications of the ACM, 46(12), 33-34.

[85] Tabachnick, B.G. and Fidell, L.S. (2007), Using Multivariate Statistics (5th ed.). New York: Allyn and Bacon.

[86] Unni, R., \& Harmon, R. (2007). Perceived effectiveness of push vs. pull mobile location based advertising. Journal of Interactive advertising, 7(2), 28-40.

[87] Venkatesh and Davis A, Theoretical Extension of the Technology Acceptance Model: Four Longitudinal Field Studies Management Science Vol. 46, No. 2, February 2000 pp. 186-204.

[88] Wang, Y., Lin, H., \&Luarn, P. (2006). 'Predicting consumer intention to use mobile service.' Information Systems Journal, 16(2), 157

[89] Wu, C. H., Kao, S. C., \& Yang, K. D. (2012). Acceptance of real-time location-based advertising service: a conceptual examination. Journal of Location Based Services, 6(4), 250-269. 
International Journal of Management and Information Technology

[90] Wu, J. H., \& Wang, S. C. (2005). What drives mobile commerce?: An empirical evaluation of the revised technology acceptance model. Information \& management, 42(5), 719-729.

[91] Wu, G., "The Role of Perceived Interactivity in Interactive Ad Processing", Doctoral Dissertation, The University of Texas at Austin, 2000.

[92] Xu, H., Oh, L. B., \&Teo, H. H. (2009). Perceived effectiveness of text vs. multimedia Location-Based Advertising messaging. International Journal of Mobile Communications, 7(2), 154-177.

[93] Xu, Heng, and Sumeet Gupta. The effects of privacy concerns and personal innovativeness on potential and experienced customers' adoption of location-based services. Electronic Markets 19.2-3 (2009): 137-149.

[94] Xu, H., Teo, H. H., \& Tan, B. (2005). Predicting the adoption of location-based services: the role of trust and perceived privacy risk. ICIS 2005 Proceedings, 71.

[95] Xu, Haifeng, and Zhuolun Li. "Advertising In New Media: Exploring Adoption of Location-Based Mobile Application Advertising." (2014).

[96] Yeh, Y. S., \& Li, Y. M. (2009). Building trust in m-commerce: contributions from quality and satisfaction. Online Information Review, 33(6), 1066-1086.

[97] Zarmpou, T., Saprikis, V., Markos, A., \&Vlachopoulou, M. (2012). Modeling users' acceptance of mobile services. Electronic Commerce Research, 12(2), 225-248.

[98] Zhang, Jing, and En Mao. Understanding the acceptance of mobile SMS advertising among young Chinese consumers. Psychology \& Marketing 25.8 (2008): 787-805. 